\title{
PENINGKATAN HASIL DAN KEAKTIFAN SISWA KELAS VI MATERI PLANET DALAM TATA SURYA MELALUI PARTNER CARD
}

\author{
Ahmad Safii \\ SD Negeri Candi Kecamatan Todanan Kabupaten Blora \\ Email: syafiia851@gmail.com
}

\begin{tabular}{l} 
Info Artikel \\
\hline Sejarah Artikel: \\
Diserahkan 19 Januari 2020 \\
Direvisi 9 Maret 2020 \\
Direvisi 2 Mei 2020 \\
Direvisi 17 Mei 2020 \\
Disetujui 22 Mei 2020 \\
\hline
\end{tabular}

Keywords:

learning outcome, student activeness, partner card models

\section{Abstract}

The purpose of this study was to improve the results and activeness of learning natural science of planetary material in the solar system in Grade VI students of SDN Candi, Todanan District, Blora Regency.

This study uses a partner card learning model by inviting students to understand concepts through paired card games. The methods used in partner cards include: discussion, discovery, and question and answer by training students to be active and creative in learning. Before using the model student learning outcomes were very low, from 20 students showing that there were as many as 3 students (15\%) and as many as 17 students (85\%) unfinished, causing an average student grade of 39.5. In early learning, many students are lazy in learning and students tend to not be active in every activity. Many students forget the material that has been taught, both easy and difficult. In addition students also did not look active in group discussions and only a few students who seemed active.

Based on student learning outcomes in the first learning cycle where the partner card game model has been known as many as 15 students or $75 \%$ have been completed and 5 students or $25 \%$ have not been completed. In the second cycle there was an increase in the number of students who had finished up by 18 students or $90 \%$ and only 2 students or $10 \%$ had not yet completed. The activeness of students in the first cycle also increased, with an average score of 3.2 in the good category and again in the second cycle of 3.6 in the excellent category.

\begin{abstract}
Abstrak
Tujuan penelitian ini adalah untuk meningkatkan hasil dan keaktifan belajar IPA materi planet dalam tata surya pada siswa kelas VI SDN Candi Kecamatan Todanan Kabupaten Blora.

Penelitian ini menggunakan model pembelajaran partner card yaitu dengan mengajak siswa untuk memahami konsep melalui permainan kartu berpasangan. Metode yang digunakan dalam partner card antara lain: diskusi, penemuan, serta tanya jawab dengan melatih siswa untuk aktif dan kreatif dalam pembelajaran. Sebelum menggunakan model tersebut hasil belajar siswa sangat rendah yaitu dari 20 siswa menunjukkan yang telah tuntas sebanyak 3 siswa $(15 \%)$ dan belum tuntas sebanyak 17 siswa ( $85 \%)$ sehingga menyebabkan nilai rata-rata siswa sebesar 39,5. Pada pembelajaran awal banyak siswa yang malas dalam belajar dan siswa cenderung tidak aktif setiap kegiatan. Siswa banyak yang lupa dengan materi yang sudah diajarkan baik yang mudah maupun sulit. Selain itu siswa juga tidak terlihat aktif dalam diskusi kelompok dan hanya beberapa siswa saja yang terlihat aktif.

Berdasarkan hasil belajar siswa pada pembelajaran siklus I dimana telah menggunakan model permainan partner card diketahui sebanyak 15 siswa atau $75 \%$ telah tuntas dan 5 siswa atau $25 \%$ belum tuntas. Pembelajaran pada siklus II terjadi peningkatan yaitu siswa yang telah tuntas naik sebanyak 18 siswa atau $90 \%$ dan hanya 2 siswa atau $10 \%$ belum tuntas. Keaktifan siswa pada siklus I juga mengalami kenaikan yaitu rata-rata skor sebesar 3,2 dengan kategori baik dan naik lagi pada siklus II sebesar 3,6 dengan kategori amat baik.
\end{abstract}

(C) 2020 Universitas Muria Kudus 


\section{PENDAHULUAN}

Dalam mata pelajaran Ilmu Pengetahuan Alam banyak materi yang mewajibkan siswa untuk melakukan penelitian dan pengamatan sehingga siswa harus terlibat langsung dalam pembelajaran tersebut. Selain itu banyak mata pelajaran IPA yang materinya berupa hafalan dan berhubungan dengan daya ingat siswa tersebut. Terlebih lagi banyak godaan dan hambatan yang dialami oleh siswa.

Pada era globlisasi ini seperti sekarang ini siswa terlalu asyik dengan dunia games yang mulai marak akhir-akhir ini dan sangat mudah dijumpai lewat telepon pintar maupun dengan komputer melalui internet. Faktor itulah yang menyebabkan ketidakberhasilan guru dalam menyampaikan materinya dengan baik.

Hasil belajar dan keaktifan siswa dalam mengikuti pelajaran Ilmu Pengetahuan Alam sangat rendah khususnya materi planet-planet dalam tata surya. Hal ini dapat dilihat bahwa dari 20 siswa nilai hasil belajar menunjukkan sebanyak tiga siswa atau sebesar $15 \%$ sudah tuntas sedangkan sebanyak 17 siswa atau sebanyak $85 \%$ belum tuntas, sedangkan nilai rata-rata yang diperoleh siswa yaitu sebesar 39,5.

Nilai terendah yang diperoleh siswa dalam materi tersebut sebesar 0 , sedangkan nilai tertinggi yang diperoleh siswa sebesar 80. Dalam hal ini Kriteria Ketuntasan Minimal (KKM) yang digunakan sebagai standar yaitu sebesar 60 . Pengambilan data tentang keaktifan siswa diambil dari lembar observasi yang dilakukan oleh teman sejawat.

Pada pembelajaran awal banyak siswa yang malas dalam belajar dan siswa cenderung tidak aktif dalam setiap kegiatan. Siswa banyak yang lupa dengan materi yang diajarkan baik yang mudah maupun yang sulit. Selain itu siswa juga tidak terlihat aktif dalam diskusi kelompok dan hanya beberapa siswa saja yang terlihat aktif.

Penyebab rendahnya hasil belajar dan keaktifan siswa terhadap materi planet dalam tata surya ada banyak faktor yaitu dari segi metode yang digunakan guru dan kemampuan berpikir siswa. Dari segi metode yang digunakan guru dalam memberikan materi masih bersifat klasikal. Metode yang digunakan guru terlalu monoton yaitu hanya dengan ceramah. Selain itu alat peraga yang digunakan kurang menarik. Hal tersebut menyebabkan siswa kurang antusias dan bersemangat dalam menerima pelajaran. Sedangkan jika dilihat dari segi potensi siswa rata-rata siswa kurang aktif dan malas dalam mengikuti pelajaran IPA materi planet-planet dalam tata surya.

Untuk mengatasi hal tersebut guru harus pandai mencari strategi yang tepat dalam meningkatkan hasil belajar dan motivasi siswa dengan mencari metode dan model pembelajaran yang menarik terhadap siswa. Metode yang digunakan haruslah bervariasi dan dapat membuat suasana kelas menjadi lebih hidup. Selain itu model pembelajaran yang digunakan haruslah mampu menumbuhkan semangat belajar siswa menjadi lebih meningkat.

Sebelumnya telah banyak penelitian yang dilakukan untuk meningkatkan hasil belajar dan keaktifan siswa pada mata pelajaran IPA, antara lain riset Khamdun (2014), Masanah (2016), riset Khakim, Utaminingsih, dan Fakhriyah (2015), penelitian Wati, Utaminingsih, dan Fakhriyah (2015) serta riset Malik (2019). Namun riset yang dilakukan berbeda dari penelitian yang sudah ada. Perbedaan riset yang dilakukan dengan penelitian terdahulu tercermin pada tujuan dari penelitian ini yaitu untuk mengetahui meningkatkan hasil belajar dan keaktifan siswa dalam memahami materi planet dalam tata surya pada siswa kelas VI SDN Candi semester 2 tahun pelajaran 2017/2018.

\section{METODE PENELITIAN}

Penelitian Tindakan Kelas (PTK) ini dilaksanakan dari bulan Februari 2018 sampai April 2018. Adapun Jadwal pelaksanaan penelitian dimulai dari pra siklus tanggal 14 Pebruari 2018.

Siklus I dilaksanakan sebanyak 3 kali pertemuan yaitu tanggal 21 Pebruari 2018, 27 Pebruari 2018 dan 28 Pebruari 2018. Sedangkan siklus II dilaksanakan pada tanggal 1 Maret 2018, 8 Maret 2018, dan 14 Maret 2018.

Penelitian ini dilaksanakan di SD Negeri Candi Kecamatan Todanan Kabupaten Blora pada siswa kelas 6. Penelitian ini diikuti oleh pada siswa kelas VI SDN Candi Kecamatan Todanan tahun pelajaran 2017/2018 berjumlah 20 siswa yang terdiri dari 13 siswa laki-laki dan 7 siswa perempuan.

Sumber data dalam penelitian ini adalah data primer dan data sekunder. Data primer yang digunakan adalah nilai ulangan harian dan informasi sebagai data awal dari hasil tes siklus I dan siklus II. Sedangkan data sekunder diambil 
dari pengamatan yang dilakukan oleh teman sejawat.

Dalam mengumpulkan data, teknik yang digunakan dalam melaksanakan kegiatan pembelajaran pada materi planet dalam tata surya melakukan evaluasi setelah akhir pembelajaran dengan memberikan tes tertulis. Dalam melakukan pengamatan, penelitian ini dibanu oleh teman sejawat. Sedangkan alat yang dipakai untuk mengumpulkan data antara lain; butir soal tertulis, kisi-kisi soal, dan lembar pengamaran atau observasi. Standar yang dibut guru dalam penelitian ini antara lain : (1) mengumpulkan data dari hasil pengamatan teman sejawar yang telah dibuatkan skor; (2) pengumpulan data tersebut dianalisis berdasarkan kriteria atau standar dengan membuat Kriteria Ketuntasan Minimal (KKM) sebesar 60.

Dalam menentukan kriteria penilaian peneliti membuat subuah kriteria nantinya berguna untuk memudahkan dalam mengelompokkan nilai siswa dalam materi planet dalam tata surya dengan menggunakan model pembelajaran partner card. Kriteria tersebut antara lai : (1) skor 0 sampai 20 dengan kriteria sangat rendah; (2) skor 21 - 40 kriteria rendah; (3) skor 41 - 60 kategori sedang; (4) skor 61 - 80 kategori baik; (4) skor 81 - 100 kategori amat baik.

Indikator keberhasilan digunakan untuk mengukur keberhasilan penggunaan model pembelajaran terhadap penelitian ini. Adapun indikator keberhasilan antara lain : (1) penellitian berhasil jika ketuntasan minimal siswa mencapai 60; (2) rata-rata nilai dalam satu kelas minimal 75; (3) keaktifan siswa dalam satu kelas mencapai 3,0. Jika ketiga indikator sudah tercapai maka penggunaan model pembelajaran partner card telah tuntas atau berhasil. Penelitian ini dilaksanakan selama 2 siklus yaitu siklus I dan siklus II. Setiap siklus terdiri dari beberapa tahapan yaitu perencanaan, pelaksanaan, pengamatan, dan refleksi.

\section{HASIL DAN PEMBAHASAN \\ Hasil \\ Siklus I}

Sebelum melaksanakan pembelajaran terlebih dahulu mempersiapkan perangkat pembelajaran dan perangkat penilaian. Peneliti telah mempersiapkan Silabus yang berguna untuk acuan dalam membuat rencana pembelajaran. Pembuatan silabus harus disesuaikan dengan kurikulum yang telah ditetapkan dengan didalamnya diberikan Standar Kompetensi, Kompetensi Dasar, dan indikator.

Pelaksanaan pembelajaran pada siklus I dilakukan sebanyak 3 pertemuan dengan menggunakan model partner card. Selama pengamatan guru dibantu teman sejawat mengamati keaktifan siswa selama mengkuti proses pembelajaran dari awal sampai akhir baik pada diri sendiri maupun dalam kelompok.

Adapun hasil belajar pada pembelajaran sikus I dapat dilihat pada tabel berikut ini :

Tabel 1 Tabel Hasil Belajar Siswa Siklus I

\begin{tabular}{ccc}
\hline No & Nilai Formatif & Banyak Siswa \\
\hline 1 & $20-40$ & 2 \\
2 & $41-60$ & 4 \\
3 & $61-80$ & 6 \\
4 & $81-100$ & 8 \\
& Jumlah & 20 \\
\hline
\end{tabular}

Berdasarkan tabel tersebut hasil belajar siswa sudah meningkat yaitu dari 20 siswa terdapat 15 siswa $(75 \%)$ sudah tuntas dan telah memenuhi KKM, dan terdapat lima siswa (25\%) belum memenuhi KKM atau belum tuntas. Nilai tertinggi yang diperoleh siswa pada siklus 1 adalah 100, sedangkan nilai terendah adalah 40 . Rata-rata nilai kelas pada siklus 1 mencapai 75,5.

Pada akhir pembelajaran siklus I guru melakukan refleksi bersama kolaborator untuk mengetahui berapa besar keberhasilan guru dalam meningkatkan hasil belajar siswa terhadap materi planet dalam tata surya. Refleksi yang dilakukan guru dapat terlihat bahwa keaktifan siswa pada pembelajaran siklus I dapat dilihat pada tabel berikut ini:

Tabel 2 Tabel Keaktifan Siswa Siklus I

\begin{tabular}{clc}
\hline No & \multicolumn{1}{c}{ Perilaku Siswa } & $\begin{array}{c}\text { Jumlah } \\
\text { Skor }\end{array}$ \\
\hline 1 & $\begin{array}{l}\text { Siswa bersemangat mengikuti } \\
\text { pembelajaran }\end{array}$ & 3 \\
\hline 2 & $\begin{array}{l}\text { Siswa percaya diri dalam } \\
\text { menjawab pertanyaan dari guru }\end{array}$ & 4 \\
\hline 3 & $\begin{array}{l}\text { Siswa tertarik dan merasa } \\
\text { senang terhadap pembelajaran }\end{array}$ & 3 \\
\hline 4 & $\begin{array}{l}\text { Siswa aktif bertanya terhadap } \\
\text { pembelajaran }\end{array}$ & 4 \\
\hline 5 & $\begin{array}{l}\text { Siswa tertarik dengan model } \\
\text { pembelajaran partner card }\end{array}$ & 3 \\
\hline 6 & Siswa tertarik mempelajari & 3 \\
\hline
\end{tabular}


PENINGKATAN HASIL DAN KEAKTIFAN BELAJAR SISWA KELAS VI MATERI PLANET ... REFLEKSI EDUKATIKA : Jurnal Ilmiah Kependidikan, Volume 10, Nomor 2, Juni 2020, hlm. 172-178

\begin{tabular}{clc}
\hline \multicolumn{3}{l}{ materi planet dalam tata surya } \\
\hline 7 & $\begin{array}{l}\text { Siswa berdiskusi terhadap } \\
\text { temannya }\end{array}$ & 3 \\
\hline 8 & $\begin{array}{l}\text { Siswa dapat menyelesaikan soal } \\
\text { latihan dengan baik }\end{array}$ & 2 \\
\hline \multirow{2}{*}{$\begin{array}{l}\text { Siswa pantang menyerah dan } \\
\text { bersungguh-sungguh dalam } \\
\text { mengerjakan soal }\end{array}$} & 3 \\
\hline 10 & $\begin{array}{l}\text { Siswa berdiskusi dengan } \\
\text { temannya saat mengerjakan } \\
\text { lembar kerja }\end{array}$ & 4 \\
\hline \multicolumn{2}{c}{ Jumlah Skor } & $\mathbf{3 2}$ \\
\hline \multicolumn{2}{c}{ Rata-Rata Skor }
\end{tabular}

Berdasarkan skor perolehan dari tabel tersebut maka keaktifan siswa pada siklus I mengalami perubahan yang baik yaitu rata-rata skor mencapai 3,2 dengan kategori baik. Untuk itu perbaikan dilakukan pada siklus selanjutnya.

\section{Siklus II}

Perencanaan yang dilakukan pada siklus II sama dengan pembelajaran siklus I yaitu dengan mempersiapkan perangkat pembelajaran meliputi : silabus, RPP lembar pengamatan, kisikisi soal, butir soal, kunci jawaban, media maupun alat peraga model partner card, dan analisis soal. Pelaksanaan pada siklus II tidak jauh beda dengan pembelajaran pada siklus I yaitu dengan menggunakan model pembelajaran partner card.

Pengamatan yang dilakukan pada siklus II juga mengalami kenaikan dibandingkan siklus sebelumnya. Hal ini dapat dilihat pada tabel berikut ini :

Tabel 3 Tabel Hasil Belajar Siswa Siklus II

\begin{tabular}{ccc}
\hline No & Nilai Formatif & Banyak Siswa \\
\hline 1 & $41-60$ & 2 \\
2 & $61-80$ & 6 \\
3 & $81-100$ & 12 \\
& Jumlah & 20 \\
\hline
\end{tabular}

Berdasarkan tabel diatas dujetahui sebanyak 18 siswa $(90 \%)$ sudah tuntas dan telah mencapai Kriteria Ketuntasan Minimal (KKM), dan hanya dua siswa $(10 \%)$ belum tuntas atau belum memenuhi KKM. Nilai tertinggi yang diperoleh siswa pada siklus 2 adalah 100 , sedangkan nilai terendah adalah 50. Rata-rata nilai kelas pada siklus 2 mengalamikenaikan yaitu mencapai 86 .
Refleksi yang dilakukan selama pengamatan mengenai keaktifan siswa pada siklus II mengalami kenaikan yang signifikan. Hal tersebut dapat dilihat pada tabel berikut ini:

Tabel 4 Tabel Keaktifan Siswa Siklus II

\begin{tabular}{clc}
\hline No & \multicolumn{1}{c}{ Perilaku Siswa } & $\begin{array}{c}\text { Jumlah } \\
\text { Skor }\end{array}$ \\
\hline 1 & $\begin{array}{l}\text { Siswa bersemangat mengikuti } \\
\text { pembelajaran }\end{array}$ & 4 \\
\hline 2 & $\begin{array}{l}\text { Siswa percaya diri dalam } \\
\text { menjawab pertanyaan dari guru }\end{array}$ & 4 \\
\hline 3 & $\begin{array}{l}\text { Siswa tertarik dan merasa } \\
\text { senang terhadap pembelajaran }\end{array}$ & 3 \\
\hline 4 & $\begin{array}{l}\text { Siswa aktif bertanya terhadap } \\
\text { pembelajaran }\end{array}$ & 4 \\
\hline 5 & $\begin{array}{l}\text { Siswa tertarik dengan model } \\
\text { pembelajaran partner card }\end{array}$ & 4 \\
\hline 6 & $\begin{array}{l}\text { Siswa tertarik mempelajari } \\
\text { materi planet dalam tata surya }\end{array}$ & 4 \\
\hline 7 & $\begin{array}{l}\text { Siswa berdiskusi terhadap } \\
\text { temannya }\end{array}$ & 3 \\
\hline 8 & $\begin{array}{l}\text { Siswa dapat menyelesaikan soal } \\
\text { latihan dengan baik }\end{array}$ & 3 \\
\hline 9 & $\begin{array}{l}\text { Siswa pantang menyerah dan } \\
\text { bersungguh-sungguh dalam } \\
\text { mengerjakan soal }\end{array}$ \\
\hline 10 & $\begin{array}{l}\text { Siswa berdiskusi dengan } \\
\text { temannya saat mengerjakan } \\
\text { lembar kerja }\end{array}$ & 3 \\
\hline & Jumlah Skor & $\mathbf{3 6}$ \\
\hline & Rata-Rata Skor \\
\hline
\end{tabular}

Berdasarkan skor perolehan dari tabel tersebut maka keaktifan siswa pada siklus II juga mengalami perubahan yang baik yaitu rata-rata skor mencapai 3,6 dengan kategori amat baik.

\section{Pembahasan}

Pada kondisi pra siklus pembelajaran belum menggunakan model partner card sehingga hasil belajar dan keaktian siswa sangat rendah. Model pembelajaran ini merupakan pengembangan dari model pembelajaran kartu berpasangan yaitu model pembelajaran dimana guru menyiapkan kartu yang berisi soal atau permasalahan dan menyiapkan kartu jawaban kemudian siswa mencari pasangan kartunya (Suyatno, 2009).

Untuk memperbaiki kondisi tersebut maka pembelajaran akan menggunakan model partner card. Pada siklus I hasil belajar dan keaktifan siswa mulai ada peningkatan yang 
signifikan yaitu siswa mulai ada perhatian dan lebih aktif terhadap pembelajaran sehingga berpengaruh terhadap hasil belajar siswa. Pembelajaran pada siklus II dilakukan untuk memperbaiki kekurangan pada siklus sebelumnya meliputi teknis dalam menggunakan model partner card.

Untuk lebih jelasnya peningkatan hasil belajar dan keaktian siswa dari kondisi awal sampai siklus II dapat dilihat pada tabel dibawah ini:

Tabel 5 Tabel Hasil Belajar dan Keaktifan Siswa Dari Kondisi Awal Sampai Siklus II

\begin{tabular}{llccc}
\hline \multirow{2}{*}{ No } & Uraian Kegiatan & \multicolumn{3}{c}{ Kegiatan Pembelajaran } \\
\cline { 3 - 5 } & & $\begin{array}{c}\text { Pra } \\
\text { Siklus }\end{array}$ & $\begin{array}{c}\text { Siklus } \\
\text { I }\end{array}$ & $\begin{array}{c}\text { Siklus } \\
\text { II }\end{array}$ \\
\hline A. & Hasil Belajar & & & \\
& 1. Nilai Tertinggi & 80 & 100 & 100 \\
& 2. Nilai Terendah & 0 & 40 & 50 \\
3. Rata-Rata & 39,5 & 75,5 & 86 \\
& Kelas & & 15 & 18 \\
& & 3 siswa & siswa & siswa \\
& 4. Tuntas & $(15 \%)$ & $(75 \%)$ & $(90 \%)$ \\
& & 17 & 5 & 2 siswa \\
& & 5iswa & siswa & $(10 \%)$ \\
& 5. Belum Tuntas & $(85 \%)$ & $(25 \%)$ & \\
B. & Keaktifan Siswa & & 32 & 36 \\
& 1. Jumlah Skor & & 3,2 & 3,6 \\
\hline
\end{tabular}

Berdasarkan tabel tersebut nilai tertinggi pada kondisi awal sebesar 80 dan terendah sebesar 0. Pada siklus I mengalami kenaikan yaitu nilai tertinggi mencapai 100 dan nilai terendah sebesai 40. Pada siklus II nilai tertinggi mencapai 100 dan nilai terendah sebesar 50. Nilai rata-rata setiap siklusnya juga mengalami kenaikan yaitu pada kondisi awal sebesar 39,5 selanjutnya naik sebesar 75,5 dan pada siklus II naik kembali menjadi 86 .

Pada kondisi awal siswa yang sudah tuntas sebanyak 3 siswa atau $16 \%$ sedangkan siswa yang belum tuntas sebanyak 17 siswa atau $85 \%$. Pada siklus I mengalami kenaikan sebanyak 15 siswa atau $75 \%$ telah tuntas dan lima siswa atau $25 \%$ belum tuntas. Selanjutnya pada siklus II juga mengalami kenaikan yaitu sebanyak 18 siswa atau $90 \%$ telah tuntas dan hanya dua siswa atau $10 \%$ belum tuntas.

Keaktian siswa pada siklus I mengalami perubahan yang lebih baik yaitu rata-rata sebesar
3,2 dengan kategori baik. Dilanjutkan pada siklus II mengalami kenaikan lagi dengan rata-rata sebesar 3,6 dengan kategori amat baik.

Berdasarkan uraian tersebut maka penggunaan model partner card dapat meningkatkan hasil belajar dan keaktifan siswa pada mata pelajaran IPA materi planet dalam tata surya siswa kelas VI SDN Candi semester 2 tahun pelajaran 2017/2018.

Hasil penelitian yang dilakukan memiliki persamaan dan perbedaan dengan riset Sukatmaji (2014), penelitian Simanjuntak (2017) serta riset Sari, Ahmad, dan Amsor (2019). Adapun persamaannya yaitu pada mata pelajaran IPA materi Tata Surya yang menjadi fokus penelitian. Sementara itu perbedaannya pada hasil riset yang dilakukan.

$$
\text { Penelitian Sukatmaji }
$$
menyimpulkan bahwa (1) metode inkuiri ilmiah dapat meningkatkan aktifitas belajar mata pelajaran IPA materi "sistem tata surya" siswa kelas VI SDN Darungan 04 Tanggul Jember semester gasal tahun Pelajaran 2011/2012, (2) metode inkuiri ilmiah dapat meningkatkan hasil belajar mata pelajaran IPA materi "sistem tata surya" siswa kelas VI SDN Darungan 04 Tanggul Jember semester gasal tahun Pelajaran 2011/2012. Sementara itu riset Simanjuntak (2017) menyimpulkan bahwa model pembelajaran CTL memiliki keunggulan dalam meningkatkan hasil belajar siswa pada materi Tata Surya di kelas VI SD Negeri 064954 Medan Amplas TA 2015/2016. Lebih lanjut riset Sari, Ahmad, dan Amsor (2019) menyimpulkan bahwa terdapat perbedaan peningkatan keterampilan generik sains yang signifikan antara kelas eksperimen dengan kelas kontrol setelah diterapkannya pembelajaran berbantuan aplikasi Solar System Scope pada materi Tata Surya. Hasil tes menunjukkan bahwa kelas eksperimen dan kontrol mengalami peningkatan keterampilan generik sains secara keseluruhan. Namun, peningkatan yang dialami kelas eksperimen lebih besar dibandingkan dengan kelas kontrol.

\section{SIMPULAN}

Dalam memperbaiki pembelajaran IPA materi planet dalam tata surya maka digunakan sebuah model pembelajaran partner card dengan tujuan untuk meningkatkan hasil belajar dan keaktian siswa di kelas VI SDN Candi. Berdasarkan hasil nilai siswa yang diperoleh dari 
kondisi awal siswa yaitu sebanyak tiga siswa $(15 \%)$ sudah tuntas dan siswa yang belum tuntas sebanyak 17 siswa $(85 \%)$.

Pada pembelajaran siklus I terjadi peningkatan yang signifikan yaitu sebanyak 15 siswa $(75 \%)$ telah tuntas dan siswa yang belum tuntas ada lima siswa (25\%). Pembelajaran pada siklus II juga mengalami kenaikan yaitu sebanyak 18 siswa (90\%) telah mencapai KKM, sedangkan siswa yang dibawah KKM hanya sebanyak dua siswa (10 \%). Sementara itu keaktifan siswa pada siklus I menunjukkan peningkatan yaitu rata-rata sebesar 3,2 dengan kategori baik dan terjadi peningkatan pada siklus II sebesar 3,6 dengan kategori amat baik.

\section{DAFTAR PUSTAKA}

Arikunto, Suharsini. 1998. Prosedur Penelitian suatu Pendekatan Praktik (Edisi Revisi IV). Jakarta: Rineka Cipta.

Khakim., Utaminingsih, Sri., dan Fakhriyah, Fina. 2015. Penerapan Model Contextual Teaching and Learning Melalui Pemanfaatan Lingkungan Sekitar Untuk Meningkatkan Hasil Belajar IPA Kelas V SD 1 Peganjaran Kudus. Refleksi Edukatika : Jurnal Ilmiah Kependidikan, 5 (1).

Khamdun. 2014. Peningkatkan Hasil Belajar IPA Melalui Inkuiri Terbimbing Pada Siswa SDN I Ngembalrejo Bae Kudus. Refleksi Edukatika : Jurnal Ilmiah Kependidikan, 4 (2): 1-9.

Malik, Jamaludin. 2019. Penerapan Metode Diskusi Kelompok Untuk Meningkatkan Hasil Belajar IPA Dan Aktivitas Siswa Kelas IV SD I Sidorekso Pada Materi Menggolongkan Hewan Berdasarkan Jenis Makanannya. Refleksi Edukatika : Jurnal Ilmiah Kependidikan, 9 (2): 128133.
Sari, Ika Mustika., Ahmad, Syifa Fauzi., dan Amsor. 2019. Peningkatan Keterampilan Generik Sains Pada Materi Tata Surya Melalui Pembelajaran Berbantuan Aplikasi Solar System Scope Untuk Siswa SMP. JoTaLP: Journal of Teaching and Learning Physics, 4 (2): 0117.

Setyaningsih. 2016. Penerapan Model Pembelajaran Kooperatif Tipe Make a Match Untuk Meningkatkan Hasil Belajar IPA Siswa Kelas VI SD Negeri 006 Tri Mulya Jaya Kecamatan Ukui. Jurnal Primary Prodi PGSD FKIP Universitas Riau, 5 (3): 317-331.

Simanjuntak, Ani. 2017. Meningkatkan Hasil Belajar Siswa Pada Materi Tata Surya Dengan Menggunakan Model Pembelajaran Contextual Teaching And Learning (CTL) Di Kelas VI SD Negeri 064954 Medan Amplas T.A 2015/2016. Journal of Physics and Science Learning (PASCAL), 1 (2): 35-45.

Sukatmaji. 2014. Meningkatkan Aktifitas dan Hasil Belajar Sistem Tata Surya Melalui Inkuiri Ilmiah Siswa Kelas VI SDN Darungan 04 Tanggul Jember Tahun Pelajaran 2010/2011. Pancaran, 3 (4): 7988.

Wati, Nanik Istika., Utaminingsih, Sri., dan Fakhriyah, Fina. 2015. Penerapan Model Pembelajaran Berbasis Masalah (PBM) Untuk Meningkatkan Hasil Belajar IPA Siswa di Kelas V SD Negeri Pasuruhan Pati. Refleksi Edukatika : Jurnal Ilmiah Kependidikan, 5 (1): 1-7. 